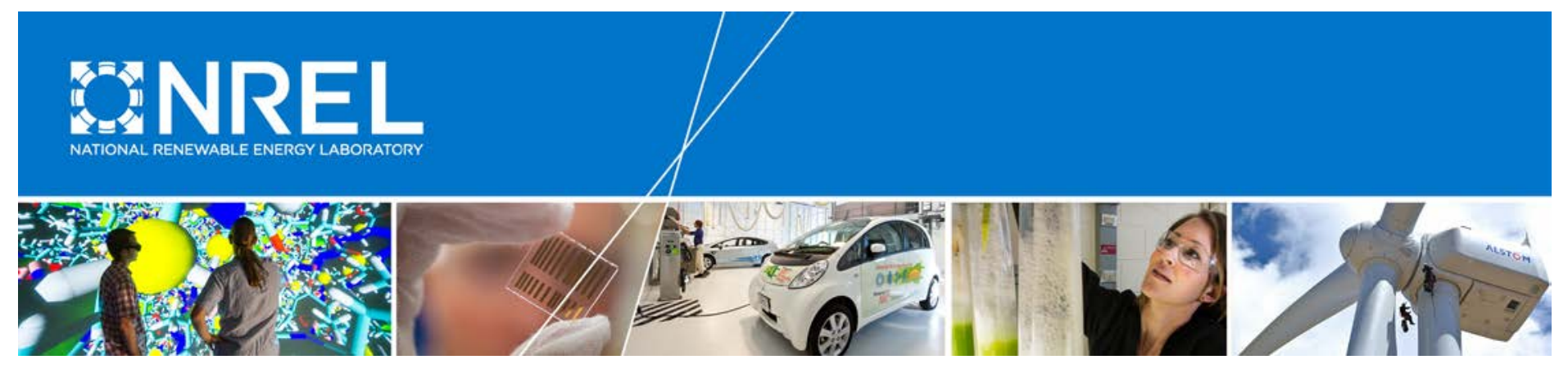

\title{
On-Road Validation of a Simplified Model for Estimating Real-World Fuel Economy
}

\section{Preprint}

Eric Wood and Jeff Gonder National Renewable Energy Laboratory

Forrest Jehlik

Argonne National Laboratory

To be presented at WCX 17: SAE World Congress Experience Detroit, Michigan

April 4-6, 2017

NREL is a national laboratory of the U.S. Department of Energy Office of Energy Efficiency \& Renewable Energy Operated by the Alliance for Sustainable Energy, LLC

This report is available at no cost from the National Renewable Energy Laboratory (NREL) at www.nrel.gov/publications.

\section{Conference Paper}

NREL/CP-5400-67682

January 2017 


\section{NOTICE}

The submitted manuscript has been offered by an employee of the Alliance for Sustainable Energy, LLC (Alliance), a contractor of the US Government under Contract No. DE-AC36-08GO28308. Accordingly, the US Government and Alliance retain a nonexclusive royalty-free license to publish or reproduce the published form of this contribution, or allow others to do so, for US Government purposes.

This report was prepared as an account of work sponsored by an agency of the United States government. Neither the United States government nor any agency thereof, nor any of their employees, makes any warranty, express or implied, or assumes any legal liability or responsibility for the accuracy, completeness, or usefulness of any information, apparatus, product, or process disclosed, or represents that its use would not infringe privately owned rights. Reference herein to any specific commercial product, process, or service by trade name, trademark, manufacturer, or otherwise does not necessarily constitute or imply its endorsement, recommendation, or favoring by the United States government or any agency thereof. The views and opinions of authors expressed herein do not necessarily state or reflect those of the United States government or any agency thereof.

This report is available at no cost from the National Renewable Energy Laboratory (NREL) at www.nrel.gov/publications.

Available electronically at SciTech Connect http:/www.osti.gov/scitech

Available for a processing fee to U.S. Department of Energy and its contractors, in paper, from:

U.S. Department of Energy

Office of Scientific and Technical Information

P.O. Box 62

Oak Ridge, TN 37831-0062

OSTI http://www.osti.gov

Phone: 865.576.8401

Fax: 865.576.5728

Email: reports@osti.gov

Available for sale to the public, in paper, from:

U.S. Department of Commerce

National Technical Information Service

5301 Shawnee Road

Alexandria, VA 22312

NTIS http://www.ntis.gov

Phone: 800.553 .6847 or 703.605 .6000

Fax: 703.605.6900

Email: orders@ntis.gov 


\title{
On-Road Validation of a Simplified Model for Estimating Real-World Fuel Economy
}

\author{
Eric Wood and Jeff Gonder \\ National Renewable Energy Laboratory
}

Forrest Jehlik

Argonne National Laboratory

\begin{abstract}
On-road fuel economy is known to vary significantly between individual trips in real-world driving conditions. This work introduces a methodology for rapidly simulating a specific vehicle's fuel economy over the wide range of real-world conditions experienced across the country. On-road test data collected using a highly instrumented vehicle is used to refine and validate this modeling approach. Model accuracy relative to on-road data collection is relevant to the estimation of "off-cycle credits" that compensate for real-world fuel economy benefits that are not observed during certification testing on a chassis dynamometer.
\end{abstract}

\section{Introduction}

U.S. fuel economy standards are driving innovations in the automotive industry to meet the 2025 Corporate Average Fuel Economy target of 54.5 miles per gallon [1]. Some of these innovations, such as those influencing powertrain thermal response or driver behavior, can be difficult to assess using standardized chassis dynamometer testing over certification drive cycles. Discrepancies between certification and real-world fuel economy are problematic, both for regulatory bodies seeking to incentivize on-road efficiency and manufacturers pursuing credit for the actual efficiency benefits of their products.

One approach to overcoming discrepancies between tested and realworld fuel economy is to develop virtual models of vehicle efficiency that can be simulated under real-world conditions. Such an approach requires an understanding not only of how well fuel economy models can be calibrated to chassis dynamometer testing, but also of their predictive accuracy for real-world efficiency estimations.

This analysis quantifies the ability of a simplified powertrain model to predict real-world fuel economy. Vehicle data from chassis dynamometer testing of a conventional gasoline sedan are used to calibrate a simplified fuel economy model. The model's predictive performance is then quantified using on-road data collected from thousands of miles of real-world driving.

\section{Vehicle Testing}

The vehicle under inspection in this work is a 2011 Ford Fusion (2.5L, 6-speed automatic). Chassis dynamometer and on-road testing were conducted between 2014 and 2016 and are summarized in Table 1.

Table 1. Testing summary on 2011 Ford Fusion.

\begin{tabular}{|l|l|l|}
\hline Year & Test Conditions & Purpose \\
\hline $\begin{array}{l}2014 \\
\text { (dyno) }\end{array}$ & $\begin{array}{l}\text { Hot/cold starts on Urban } \\
\text { Dynamometer Driving Schedule } \\
\text { (UDDS)/US06 cycles at test cell } \\
\text { temperatures from }-17^{\circ} \mathrm{C} \text { to } \\
+35^{\circ} \mathrm{C}\end{array}$ & $\begin{array}{l}\text { Measure cold start } \\
\text { engine behavior }\end{array}$ \\
\hline $\begin{array}{l}2015 \\
\text { (on-road) }\end{array}$ & $\begin{array}{l}2,843 \text { miles of on-road driving } \\
\text { under a variety of conditions }\end{array}$ & $\begin{array}{l}\text { Measure on-road } \\
\text { fuel economy }\end{array}$ \\
\hline $\begin{array}{l}2016 \\
(\text { dyno) }\end{array}$ & $\begin{array}{l}\text { Cold starts on UDDS/US06 } \\
\text { cycles at }-7^{\circ} \mathrm{C} \text { and }+22^{\circ} \mathrm{C}(\text { with } \\
\text { and without transmission oil } \\
\text { preheating) }\end{array}$ & $\begin{array}{l}\text { Measure cold start } \\
\text { transmission } \\
\text { behavior }\end{array}$ \\
\hline
\end{tabular}

\section{Chassis Dynamometer Testing}

Chassis dynamometer tests were conducted at Argonne National Laboratory's (ANL's) Advanced Powertrain Research Facility (APRF) [2] four-wheel-drive dynamometer test cell in 2014 and 2016. This dynamometer test facility is designed to handle light- to medium-duty sized (maximum $6,350 \mathrm{~kg}$ ) vehicles capable of producing up to $373 \mathrm{~kW}$ of wheel power. The test cell is U.S. Environmental Protection Agency (EPA) 5-cycle capable with ambient temperature capability from $-17^{\circ} \mathrm{C}$ to $+35^{\circ} \mathrm{C}$.

The test cell contains emission benches capable of bag measuring the criteria emissions (total hydrocarbons, oxides of nitrogen, carbon monoxide and soot) as well as carbon dioxide for cycle fuel economy. Additionally, a turbine wheel fuel cart is used to accurately measure fuel use in real time. An integrated data acquisition system allows for a multitude of controller area network, analog, and digital signals to be collected simultaneously. All data are collected and time aligned at 10 hertz frequency. The test vehicle and APRF test facility are shown in Figure 1. 


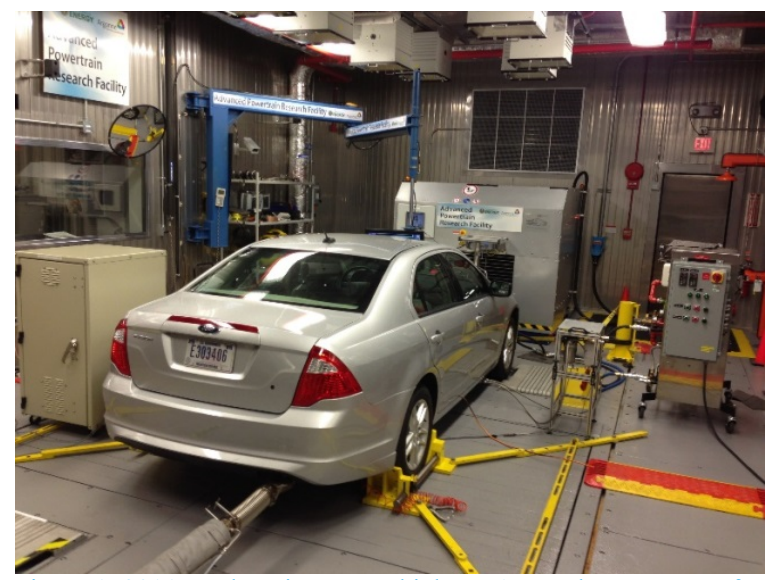

Figure 1. 2011 Ford Fusion test vehicle on APRF dynamometer for testing. Photo by Forrest Jehlik, Argonne National Laboratory

The vehicle was extensively instrumented to capture pertinent thermal and energy/power nodes. The engine was instrumented with K-type thermocouples to determine coolant, oil, air intake and exhaust temperature at various locations (including exhaust port to pre-, mid-bed, and post-catalyst). Additional K-type thermocouples were included in the transmission and vehicle interior. A strain-based torque measurement system was installed on the engine flex plate and half shafts, enabling measurement of engine out, transmission input, and transmission output torque and power. Flow measurements for fuel were calibrated within $1.8 \%$ of measured error. Engine speed and transmission gear were recorded via controller area network signals. Figure 2 represents the pertinent instrumentation types and installation locations for the work.

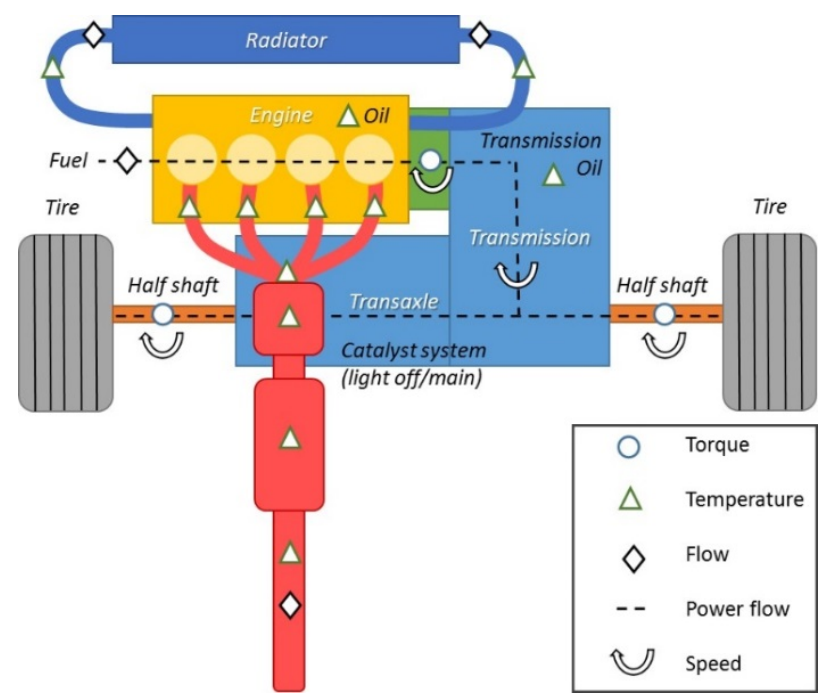

Figure 2. Test vehicle instrumentation layout.

The 2011 Fusion was tested for cold start engine performance in 2014 under the Urban Dynamometer Driving Schedule (UDDS) and US06 cycles at test cell temperatures ranging from $-17^{\circ} \mathrm{C}$ to $+35^{\circ} \mathrm{C}$. Each of these cycles was tested from cold and hot start conditions. The 2011 Fusion was tested again in 2016 as part of a sensitivity analysis on transmission oil temperature. APRF testing in 2016 included UDDS and US06 cycles at $-7^{\circ} \mathrm{C}$ and $+22^{\circ} \mathrm{C}$ with each test conducted twice: 1 ) with the entire vehicle thermally soaked to test cell temperature; and 2) with the entire vehicle soaked except for the transmission, which was preheated using external heating elements. Transmission preheating was done at a component-level thermal perturbation to exaggerate fuel economy impacts of transmission oil temperature (relevant to a separate effort).

\section{On-Road Testing}

The 2011 Ford Fusion was modified for on-road testing in 2015 by rerouting all analog and digital measurements to a mobile data acquisition system. Since fuel consumption is measured externally during APRF chassis dynamometer testing, an inline fuel flow meter was installed on the Fusion for on-road fuel economy measurement. The Fusion is shown during 2015 on-road testing in Colorado in Figure 3.

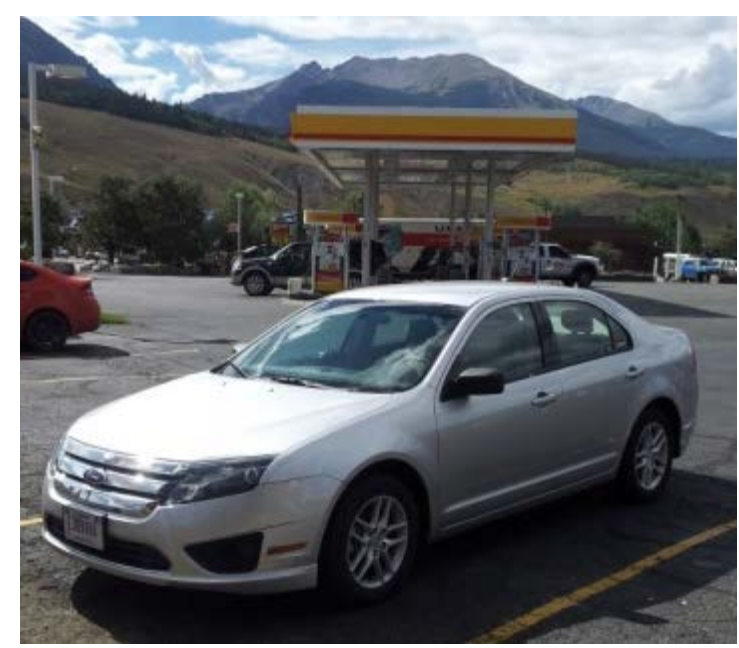

Figure 3. 2011 Ford Fusion test vehicle during on-road testing in Colorado. Photo by Eric Wood, NREL

Sample time series data from on-road testing is shown in Figures 4 to 7. For on-road testing, the fueling rate is derived from the inline flow meter; pedal position, and engine speed are obtained from the vehicle's controller area network signals; thermocouple and strain gauge torque measurements are retained from APRF instrumentation; and vehicle elevation and road grade are post-processed using global positioning system latitude/longitude coordinates per [3].

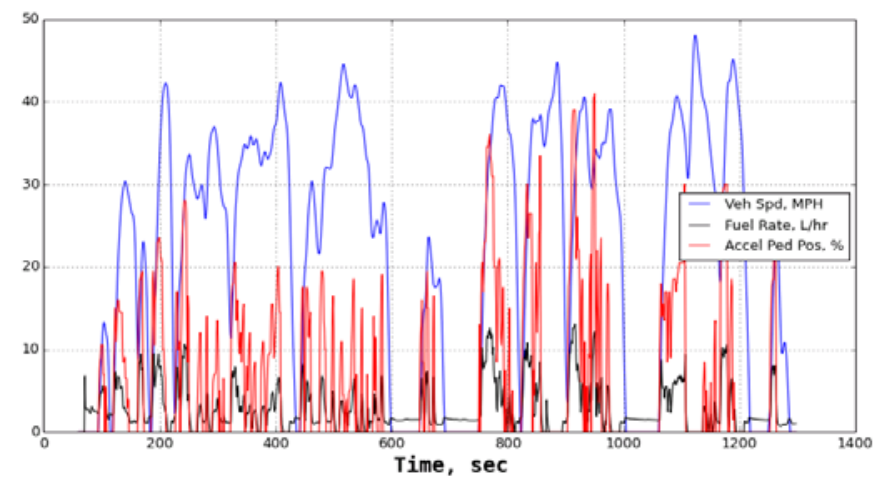

Figure 4. Vehicle speed, fuel rate, and pedal position. 


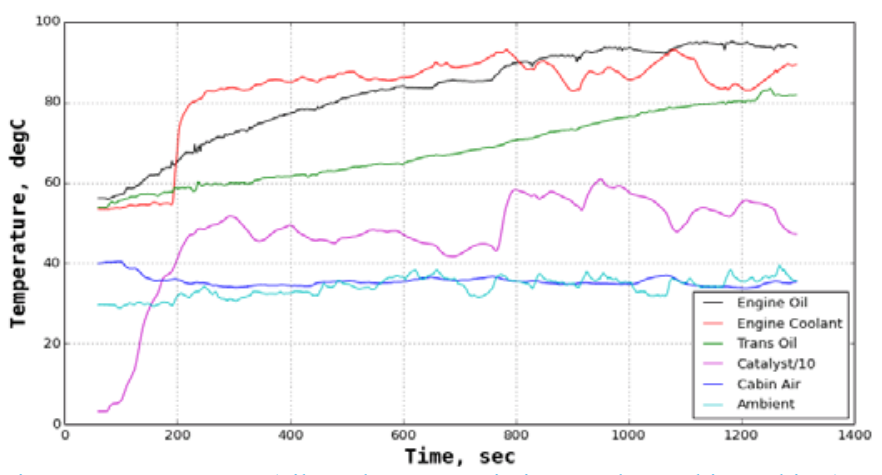

Figure 5. Temperatures (oil, coolant, transmission, catalyst, cabin, ambient).

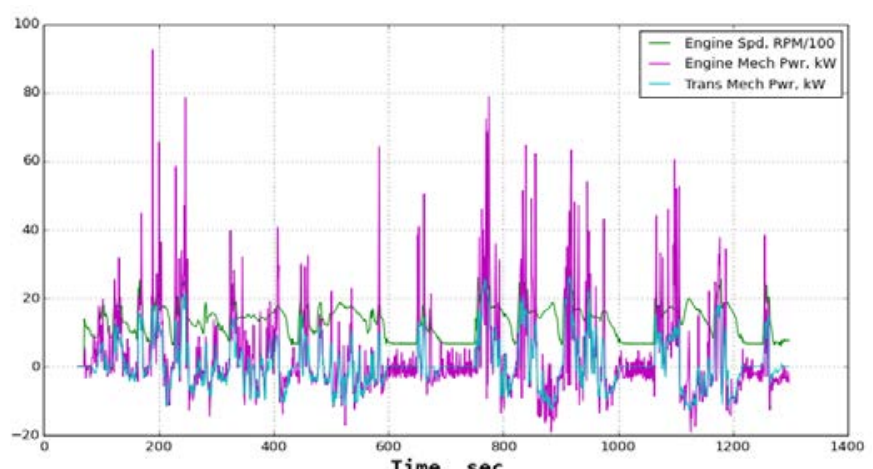

Figure 6. Engine speed and power, transmission power.
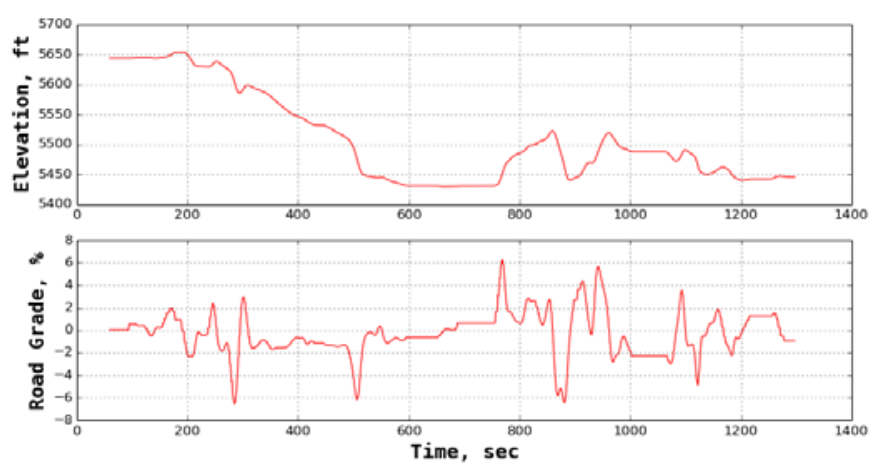

Figure 7. Elevation and road grade.

The vehicle was driven from ANL in Chicago, Illinois, to the National Renewable Energy Laboratory in Golden, Colorado. This trip enabled collection of a large volume of on-road data under a variety of highway speed, elevation, and road grade conditions. Once in Colorado, the vehicle was tested in a mix of city and highway conditions with various levels of traffic congestion. Colorado testing included three trips along the I-70 corridor into the Rocky Mountains, notorious for extended stretches of steep grade. On-road testing footprints are shown in Figures 8 to 11 at various levels of magnification.

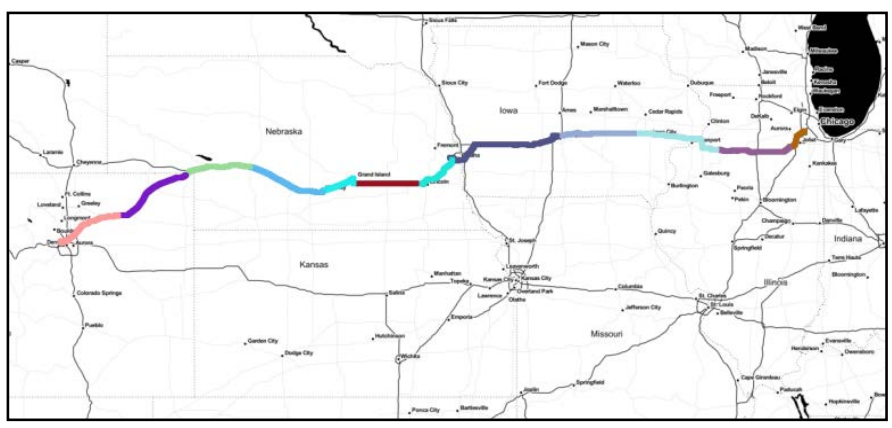

Figure 8. Rural interstates.

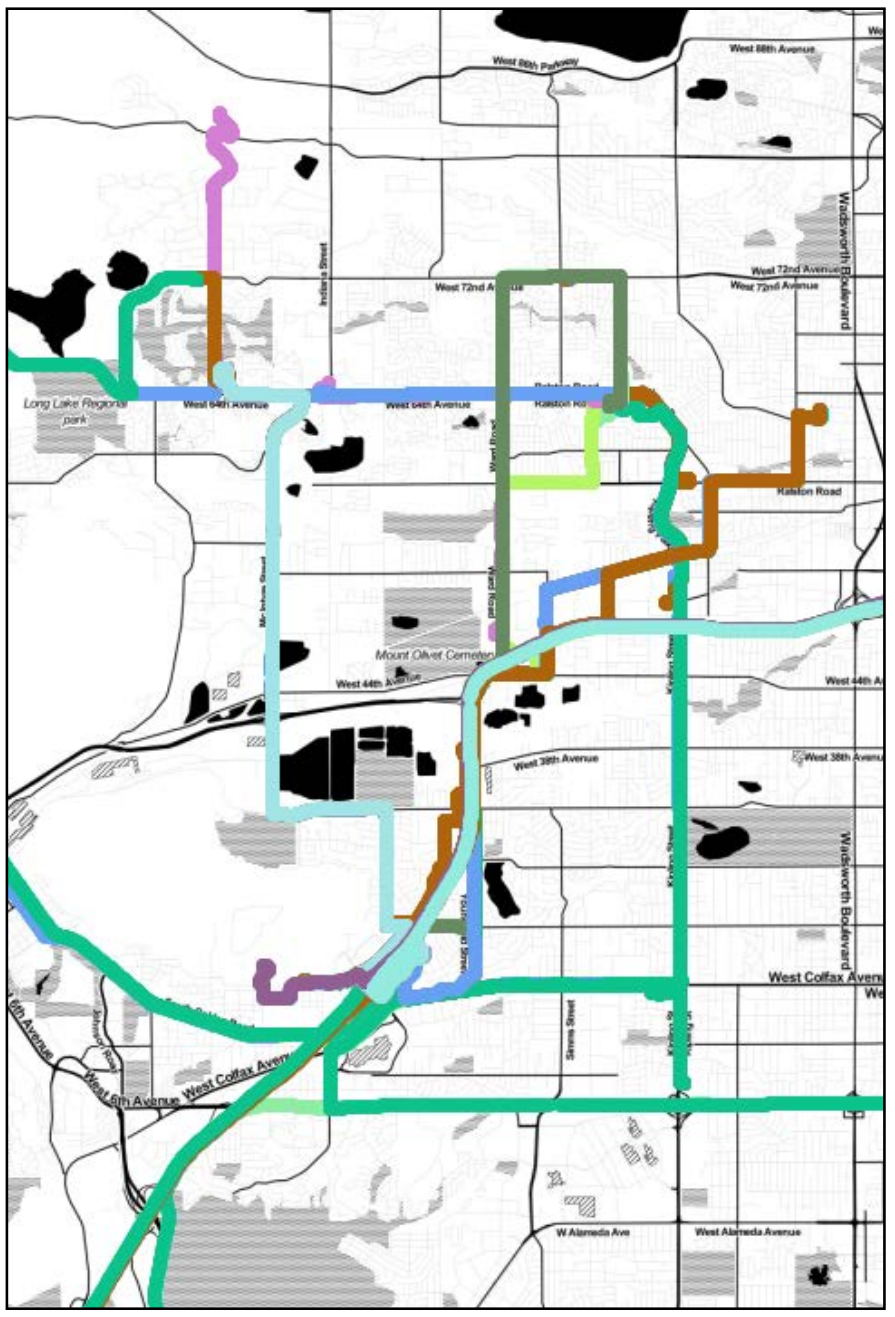

Figure 9. Arterial, collector, and local routes. 


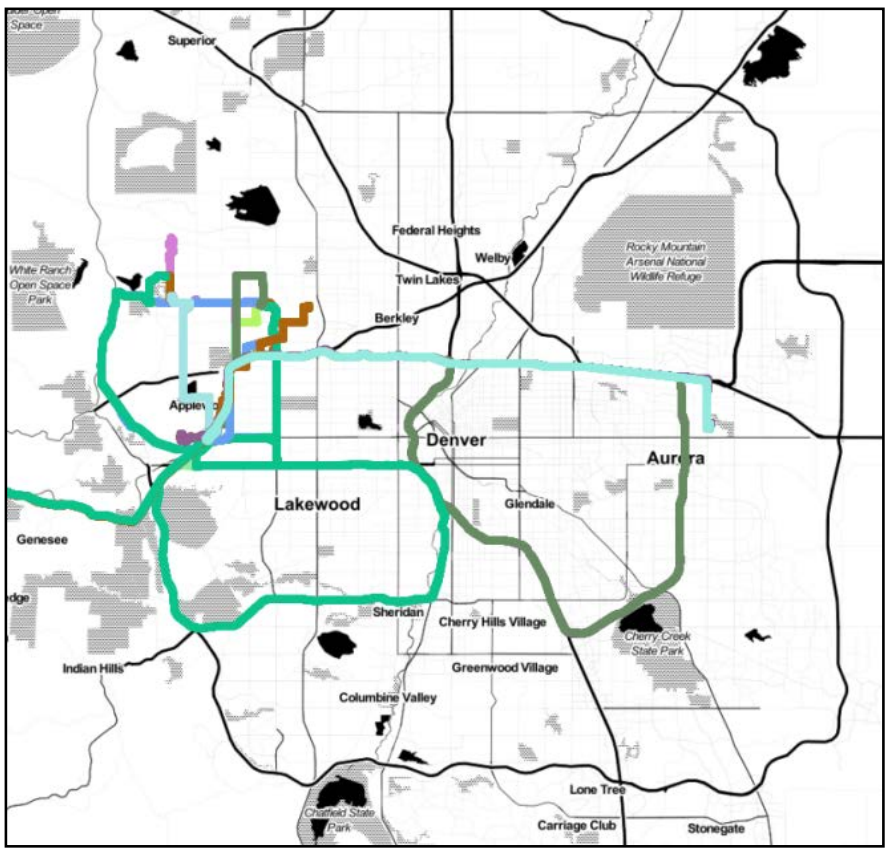

Figure 10. Urban freeways.

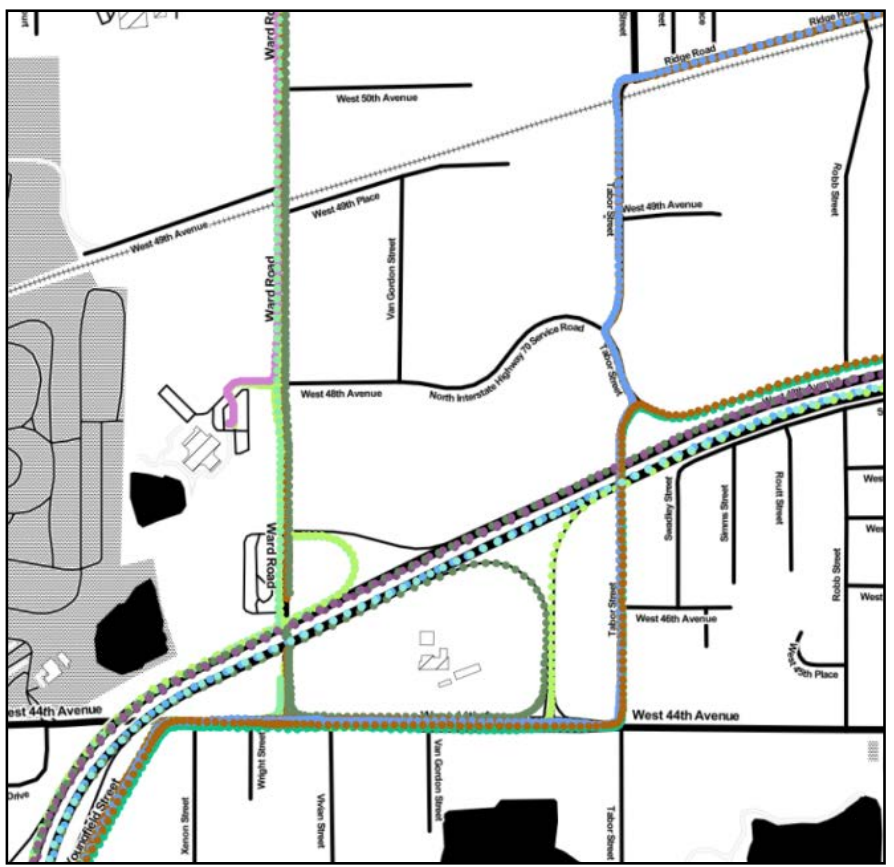

Figure 11. Arterial, collector, and local routes.

On-road data are summarized in Table 2 in terms of average driving speeds, initial engine oil temperature, ambient temperature, elevation, and road grade. The on-road dataset contains a mix of various driving conditions known to impact fuel economy.
Table 2. On-road data summary.

\begin{tabular}{|c|c|}
\hline Data collection period & Aug-Sept 2015 \\
\hline Trip count & 85 \\
\hline Total distance & 2,843 miles \\
\hline Trip average speed & $\begin{array}{l}15-75 \mathrm{mph} \\
36 \text { "highway" trips / } 49 \text { "city" } \\
\text { trips } \\
\begin{array}{l}\text { Delineation* }=40 \mathrm{mph} \text { average } \\
\text { trip speed }\end{array}\end{array}$ \\
\hline Initial engine oil temperature & $\begin{array}{l}20^{\circ} \mathrm{C}-100^{\circ} \mathrm{C} \\
32 \text { "hot" start trips / } 53 \text { "cold" } \\
\text { start trips } \\
\text { Delineation* }=80^{\circ} \mathrm{C} \text { initial oil } \\
\text { temperature }\end{array}$ \\
\hline Ambient temperature & $\begin{array}{l}17^{\circ} \mathrm{C}-38^{\circ} \mathrm{C}\left(63^{\circ} \mathrm{F}-100^{\circ} \mathrm{F}\right) \\
31 \text { trips with } \mathrm{AC} \text { on } / 54 \text { trips with } \\
\mathrm{AC} \text { off }\end{array}$ \\
\hline Elevation / Road Grade & $\begin{array}{l}535-11,100 \text { feet } \\
6 \text { trips with elevation change of } \\
\pm 3,000 \text { feet } \\
8 \text { trips with overall grade } \\
\text { exceeding } \pm 3 \% \\
\text { Delineation*: trip considered } \\
\text { "flat" if start to end elevation } \\
\text { change results in an average grade } \\
\text { between }-0.5 \% \text { and }+0.5 \%\end{array}$ \\
\hline
\end{tabular}

\section{Vehicle Modeling}

Vehicle modeling in this analysis builds off a previous effort to develop thermally sensitive maps of engine efficiency driven by lumped capacitance models of engine oil, engine coolant, and exhaust catalyst temperature [4]. A schematic of the overall simplified approach is shown in Figure 12. The approach includes backward facing calculations that start with the power required at the wheels which is scaled based on component efficiency for the transaxle, gearbox, torque converter, and engine. 

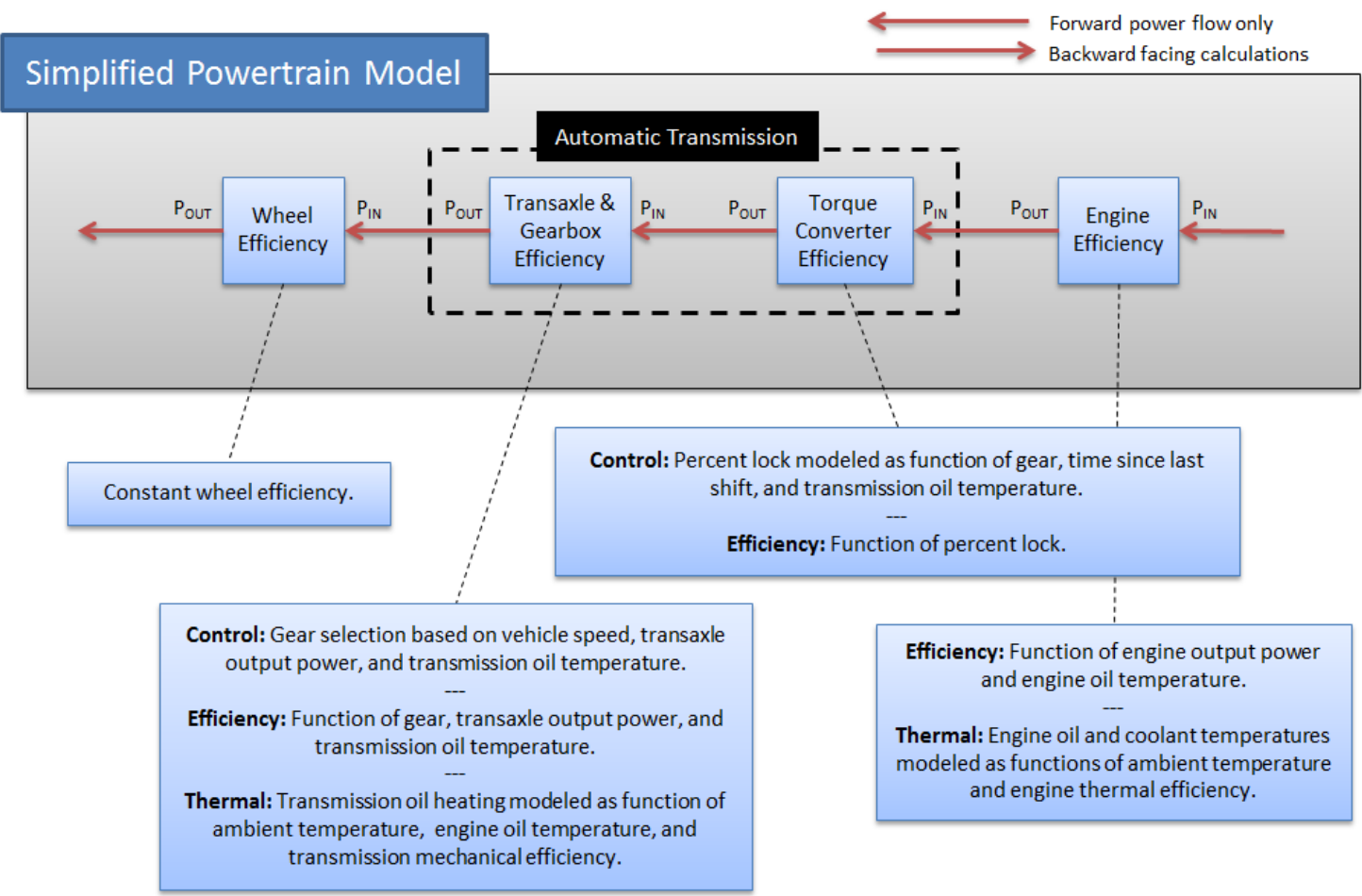

Efficiency: Function of engine output power and engine oil temperature.

Thermal: Engine oil and coolant temperatures modeled as functions of ambient temperature and engine thermal efficiency.

Figure 12. Simplified powertrain modeling schematic.

In addition to the existing models for thermally sensitive engine efficiency [4], a simplified model of transmission efficiency and its sensitivity to thermal conditions is implemented. As with the thermal models of engine and exhaust temperatures, the transmission oil temperature is modeled using a lumped capacitance approach. Tested versus modeled temperatures for engine oil, engine coolant, and transmission oil are shown in Figures 13 and 14 for a cold start UDDSx 2 at $+22^{\circ} \mathrm{C}$.

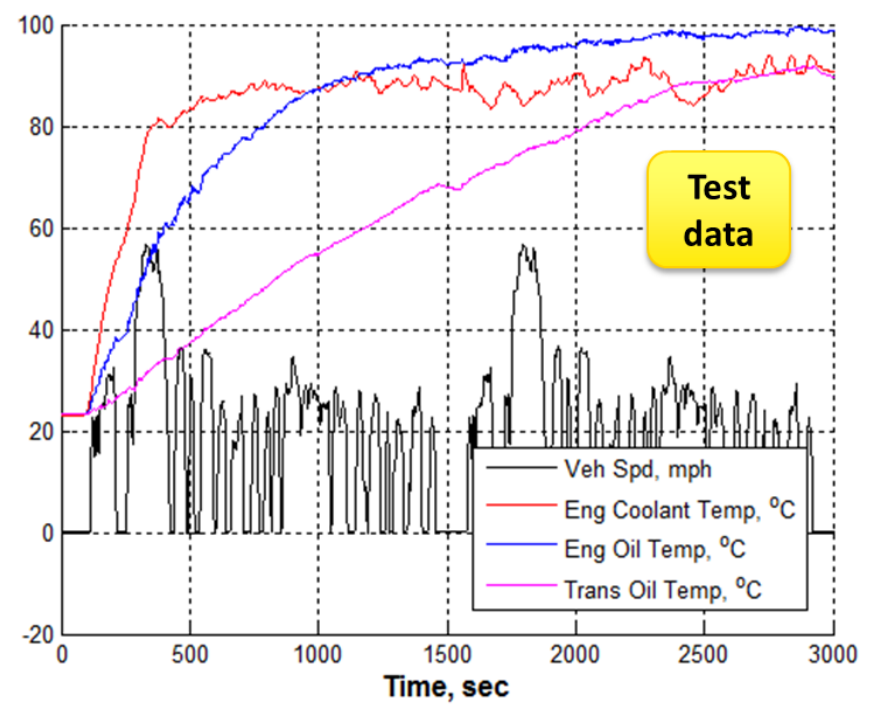

Figure 13. Cold start UDDSx2 (test data)

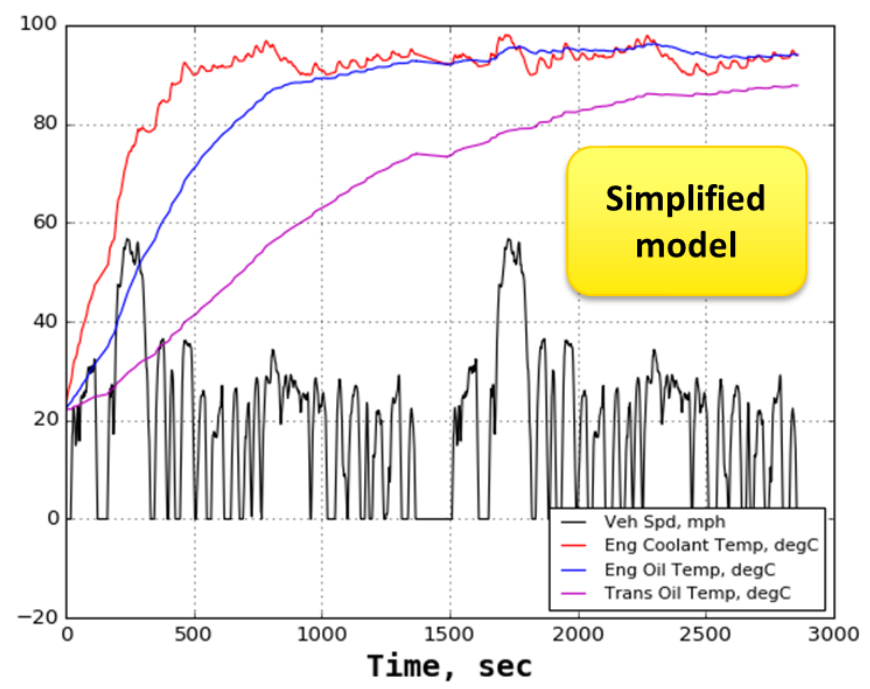

Figure 14. Cold start UDDSx2 (model).

Transmission oil temperature is used as one of the inputs to transmission mechanical efficiency by impacting shift schedule (e.g., delayed upshifts at cold transmission oil temperature), torque converter lockup (e.g., increased levels of slip at cold transmission oil temperature), and the combined mechanical efficiency of the gearbox and transaxle (e.g., increased transmission oil viscosity at low temperature). 
2016 APRF testing isolated the Fusion's combined gearbox/transaxle mechanical efficiency using a specially designed test that cycled the transmission through a series of speed, load, and gear number combinations. The test began with a cold soaked vehicle (including transmission oil) which was run through at least four repetitions of a 12-point test where vehicle speed was held constant for 30-60 seconds at each step and transmission oil temperature was allowed to naturally climb with each repetition. Test data was post-processed to calculate combined mechanical efficiency at each combination of transmission speed, load, gear, and temperature. The resulting data was fit using linear regression, which is shown in Figure 15.
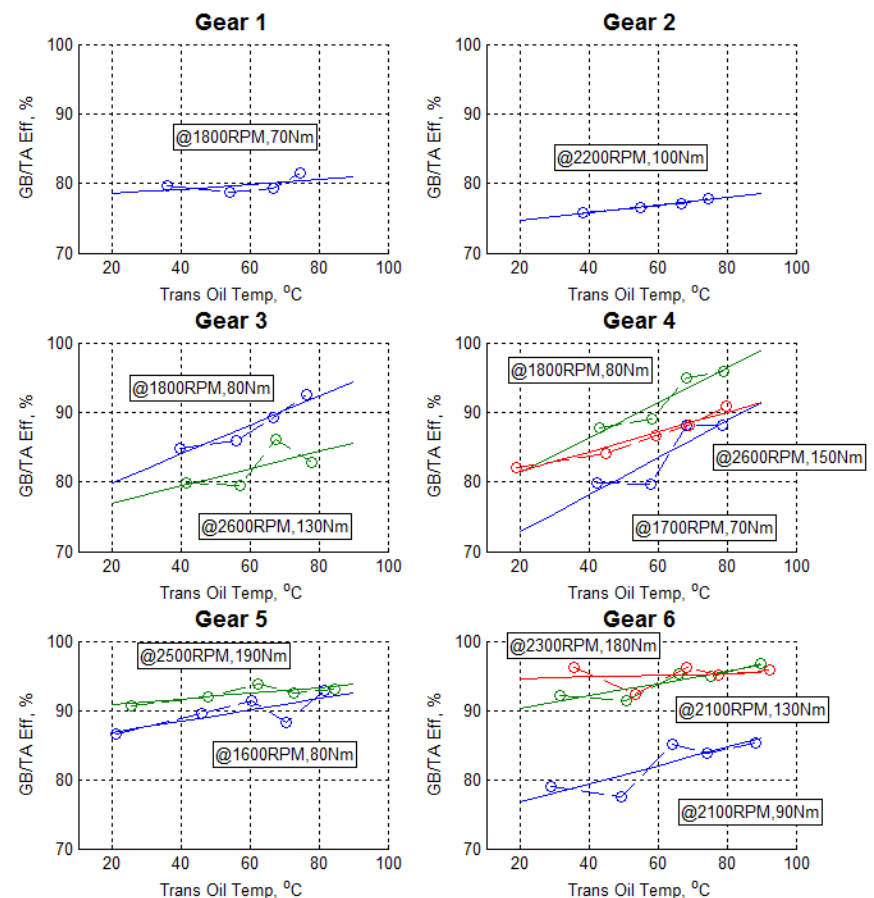

Figure 15. Linear fits of lumped transaxle and gearbox mechanical efficiency.

Thermally-sensitive transmission shifting behavior was calibrated to APRF testing in a simplified approach that relies on vehicle speed, transmission output power, and transmission oil temperature as inputs. A time series example of modeled transmission shifting behavior compared to test data is shown in Figure 16. A comparison of tested and modeled gear selection across all 16 tests from 2014 APRF testing is shown Figure 17. Modeled time in gear can be seen to match actual time for all gears to within $2 \%$.

Calculation of vehicle road loads in this analysis was performed using the National Renewable Energy Laboratory's Future Automotive Systems Technology Simulator (FASTSim) [5, 6]. FASTSim is a vehicle simulation tool used to evaluate the impact of various technologies on vehicle performance, cost, and utility in conventional and advanced technology powertrains. FASTSim calculates the power necessary to meet a given speed trace and overcome road loads (rolling, aerodynamic, kinetic, and potential) while considering component limitations, system losses, and auxiliary loads. Given the required transmission output power at each time step, transmission and engine efficiency are calculated via the thermally sensitive efficiency maps. Corresponding models for the thermal response of individual components are also updated at each time step.

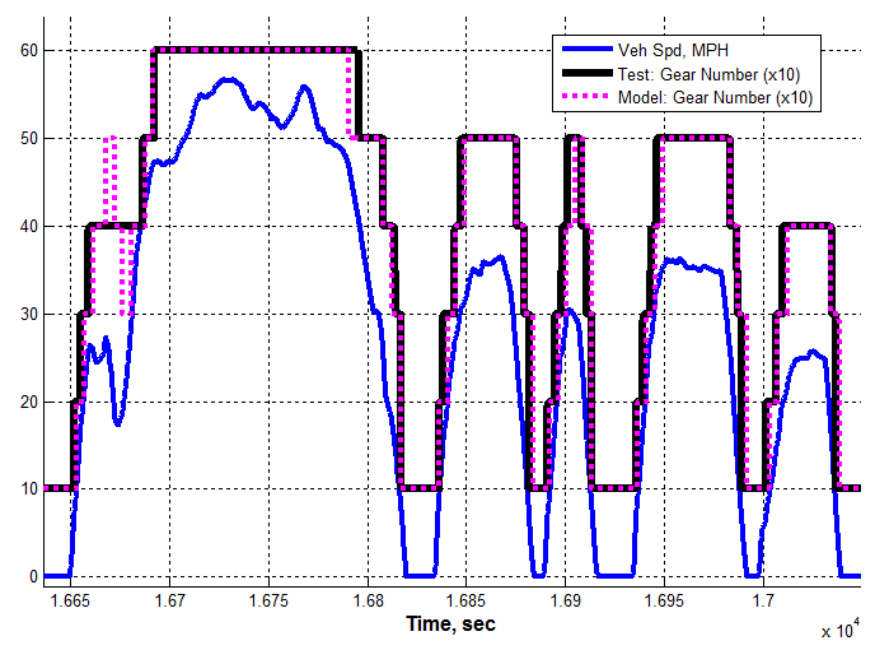

Figure 16. Example comparison between tested and modeled gear selection.

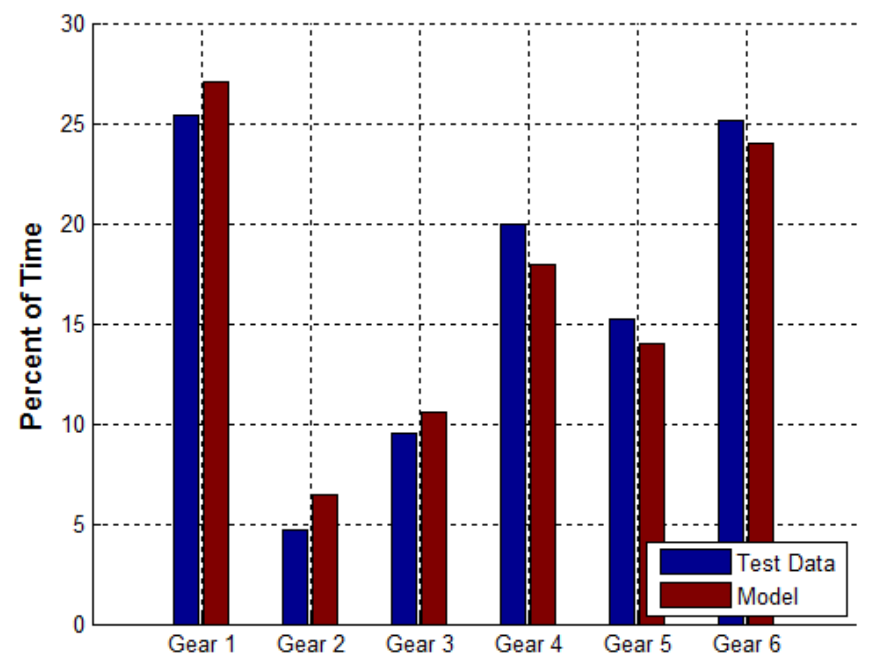

Figure 17. Time in gear comparison between test data and simplified model.

\section{Calibration to Dynamometer Testing}

Using this simplified modeling approach, laboratory fuel consumption from the 2014 APRF testing is matched to within $5.2 \%$ on all 16 laboratory test conditions with a root-mean-square error (RMSE) of $2.4 \%$. This degree of fit is believed to fall with the range of experimental cycle-to-cycle dynamometer test uncertainty [7]. A comparison between tested and modeled fuel economy for the 2014 APRF testing is shown in Figure 15. 


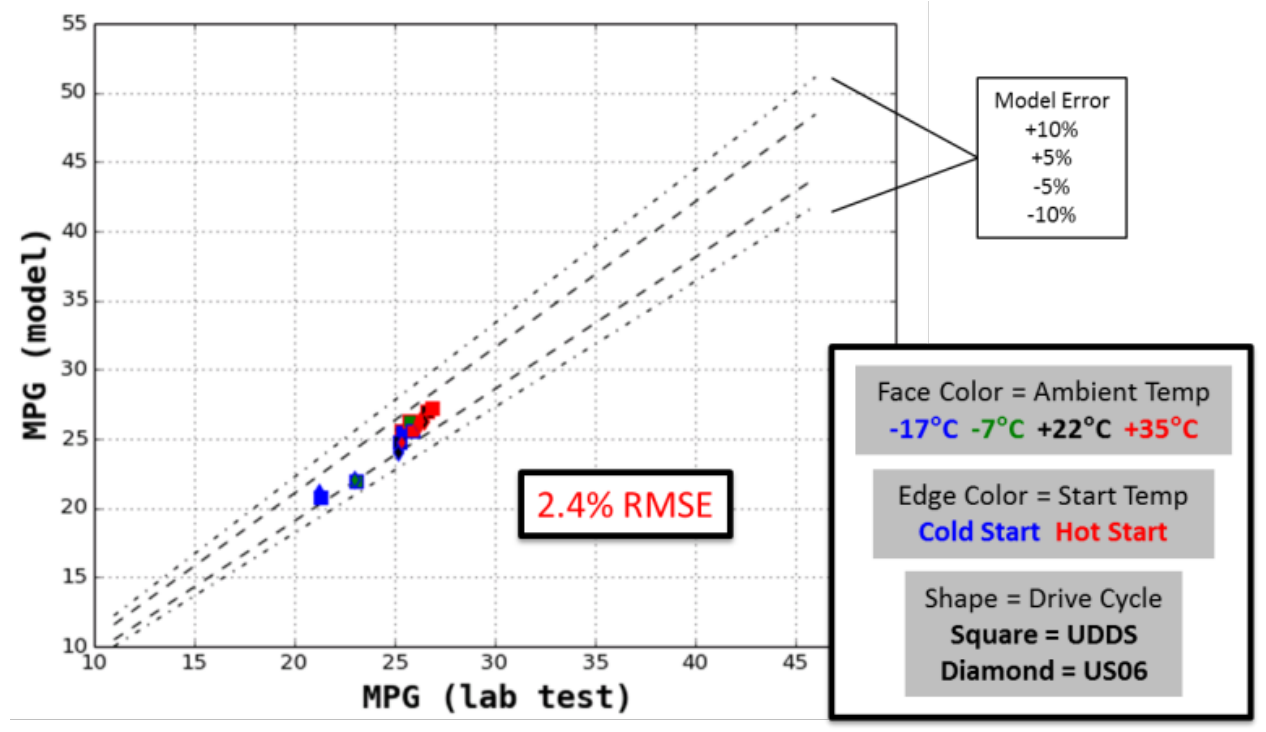

Figure 15. Tested versus modeled fuel economy agreement (dynamometer testing).

\section{Validation to On-Road Testing}

The simplified model of fuel economy for the Fusion is now applied to all 85 trips from the 2015 on-road testing. A comparison between tested and modeled fuel economy for the 2015 on-road testing is shown in Figure 16. Using the delineations defined in Table 2, markers are shown with face color, edge color, and shape based on cabin air conditioning state, initial engine thermal condition, and road grade, respectively. Vertical model error bars are placed around each marker denoting the model-simulated fuel economy sensitivity to 5 $\mathrm{mph}$ head/tail wind. Real-time wind speeds were not measured during on-road testing; however, weather station data indicate wind speeds on the order of 5-10 mph during on-road testing. The simplified modeling approach matches on-road test data with a 5.6\% RMSE.

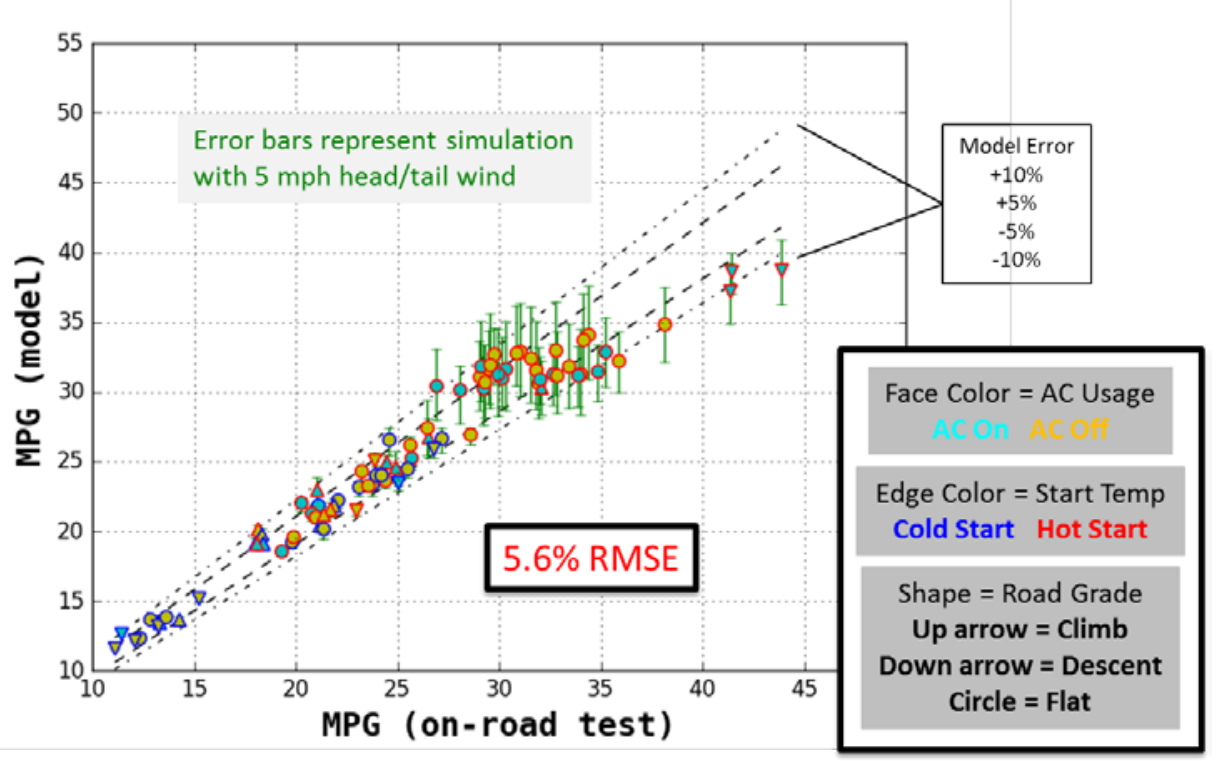

Figure 16. Tested versus modeled fuel economy agreement (on-road testing).

The primary finding when comparing model accuracy between dynamometer and on-road testing (Figures 14 and 15) is that the model's predictive power is higher when applied to the dynamometer data. This is an intuitive result given test data from the highly controlled laboratory environment excluded factors such as variable air density, road grade, air conditioning, and wind. It is also important to note the significantly larger spread in on-road fuel economy when compared to the dynamometer testing (on-road: $11-$ $46 \mathrm{mpg}$; dynamometer: $22-27 \mathrm{mpg}$ ).

To demonstrate the importance of individual on-road factors, the simplified fuel economy model was run multiple times with various levels of knowledge regarding environmental conditions. The RMS error was recorded for all model iterations. The results of this sensitivity analysis are shown in Figure 17. 


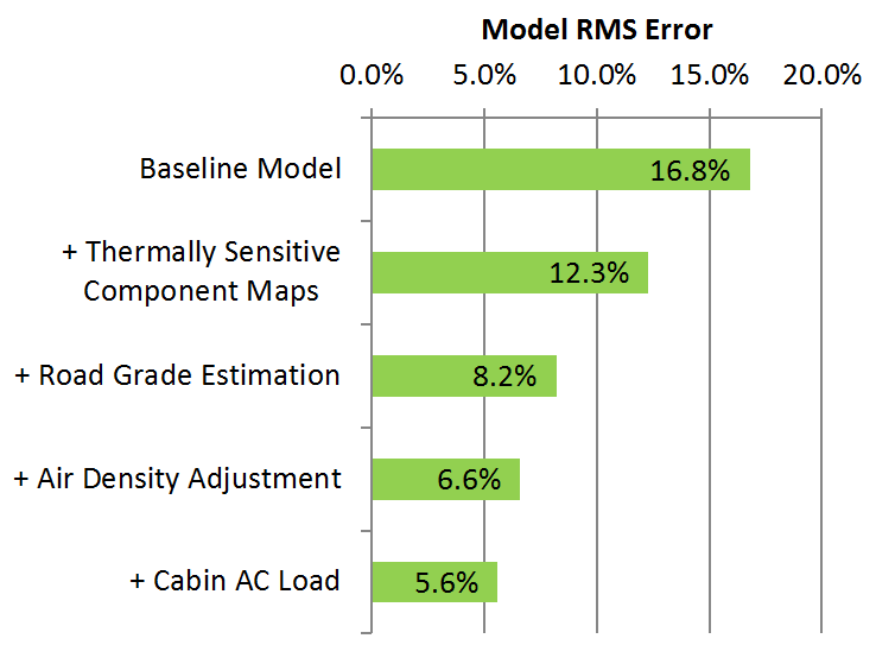

Figure 17. Model RMS error over all 85 on-road tests subject to various levels of knowledge regarding environmental conditions.

This sensitivity analysis demonstrates the relative importance of each on-road factor considered in the model. From a baseline model that neglects relevant on-road features, we see a model RMS error of $16.8 \%$. As features are added to the model (including thermally sensitive component maps coupled with ambient temperature and current vehicle thermal state, road grade estimates at every driving location, air density adjustments based on ambient temperature and elevation, and cabin air conditioning operation), we see model RMS error decrease to $5.6 \%$. This result highlights the importance of accounting for non-dynamometer effects when making estimations of real-world fuel economy.

\section{Summary}

Extensive dynamometer and on-road test data have been presented for a representative, conventional gasoline sedan. A simplified powertrain model, including thermal sensitivities to engine and transmission oil temperature, was calibrated to dynamometer data from a controlled laboratory environment with an RMS error of $2.4 \%$. Application of the simplified model to on-road data produced an RMS error of $5.6 \%$. The increase in model error observed in the on-road data demonstrates the difficulty in accurately predicting realworld fuel economy and necessitates appropriate treatment of realworld driving conditions including ambient temperature, road grade, air density, cabin climate control loads, and wind speed and direction.

\section{References}

1. The White House, Office of the Press Secretary, "Obama Administration Finalizes Historic 54.5 mpg Fuel Efficiency Standards." http://www.whitehouse.gov/the-pressoffice/2012/08/28/obama-administration-finalizes-historic-545mpg-fuel-efficiency-standard, accessed November 19, 2014.

2. Argonne National Laboratory, Transportation Technology R\&D Center. "Advanced Powertrain Research Facility (APRF)," http://www.transportation.anl.gov/facilities/aprf.html, accessed October 1, 2014.

3. Wood, E., J. Burton, A. Duran, J. Gonder, J., et al., Appending High Resolution Elevation Data to GPS Speed Traces for vehicle Energy Modeling And Simulation. Golden, CO: National
Renewable Energy Laboratory, Technical Report TP-540061109, http://www.nrel.gov/docs/fy14osti/61109.pdf.

4. Jehlik, F., E. Wood, J. Gonder, and S. Lopp. "Simulated RealWorld Energy Impacts of a Thermally Sensitive Powertrain Considering Viscous Losses and Enrichment" SAE Technical Paper 2015-010342. http://www.nrel.gov/docs/fy15osti/63255.pdf.

5. Brooker, A., J. Gonder, L. Wang, E. Wood et al., "FASTSim: A Model to Estimate Vehicle Efficiency, Cost and Performance," SAE Technical Paper 2015-01-0973, 2015, doi:10.4271/201501-0973.

6. National Renewable Energy Laboratory. "Future Automotive Systems Technology Simulator," www.nrel.gov/fastsim, accessed October 1, 2013.

7. “J-2951 Dynamometer Repeatability Testing." 2013. ANL internal study, http://standards.sae.org/i2951 201111/

\section{Contact Information}

Transportation and Hydrogen Systems Center

National Renewable Energy Laboratory

15013 Denver West Pkwy MS 1634

Golden, CO 80401

Eric Wood

(303) 275-3290

eric.wood@nrel.gov

Jeffrey Gonder

(303) 275-4462

jeff.gonder@nrel.gov

Advanced Powertrain Research Facility

Argonne National Laboratory

Energy Systems Division

9700 S. Cass Ave.

Argonne, IL 60439

Forrest Jehlik

(630) 252-6403

fjehlik@anl.gov

\section{Acknowledgments}

This work was supported by the U.S. Department of Energy under Contract No. DE-AC36-08GO28308 with the National Renewable Energy Laboratory. Funding provided by the U.S. Department of Energy's Vehicle Technologies Office. The authors would specifically like to thank Vehicle Systems Program Managers David Anderson and Lee Slezak for their guidance.

The U.S. Government retains and the publisher, by accepting the article for publication, acknowledges that the U.S. Government retains a nonexclusive, paid-up, irrevocable, worldwide license to publish or reproduce the published form of this work, or allow others to do so, for U.S. Government purposes. 


\section{Definitions/Abbreviations}

${ }^{\circ} \mathrm{C}$

degrees Celsius

ANL Argonne National Laboratory

APRF Advanced Powertrain Research Facility

EPA U.S. Environmental Protection Agency

FASTSim Future Automotive Systems Technology Simulator

mpg miles per gallon

NREL National Renewable Energy Laboratory

RMSE root-mean-square error

UDDS Urban Dynamometer Driving Schedule (EPA defined)

UDDSx2 back-to-back UDDS driving tests

US06 US06 dynamometer driving schedule (EPA defined)

US06x2 back-to-back US06 dynamometer driving tests

This report is available at no cost from the National Renewable Energy Laboratory (NREL) at www.nrel.gov/publications. 